\title{
Matrix Metalloproteinases Expressed by Astrocytes Mediate Extracellular Amyloid- $\beta$ Peptide Catabolism
}

\author{
Ke-Jie Yin, ${ }^{1}$ John R. Cirrito, ${ }^{1,2}$ Ping Yan, ${ }^{1}$ Xiaoyan Hu, ${ }^{1}$ Qingli Xiao, ${ }^{1}$ Xiaoou Pan, ${ }^{3,4}$ Randall Bateman, ${ }^{1}$ Haowei Song, ${ }^{5}$ \\ Fong-Fu Hsu, ${ }^{5}$ John Turk, ${ }^{5}$ Jan Xu, ${ }^{1}$ Chung Y. Hsu, ${ }^{6}$ Jason C. Mills, ${ }^{3,4}$ David M. Holtzman, ${ }^{1,3}$ and Jin-Moo Lee ${ }^{1}$ \\ ${ }^{1}$ Department of Neurology and the Hope Center for Neurological Disorders, and Departments of ${ }^{2}$ Psychiatry, ${ }^{3}$ Molecular Biology and Pharmacology, \\ ${ }^{4}$ Pathology and Immunology, and ${ }^{5}$ Internal Medicine, Division of Endocrinology, Diabetes, Metabolism, and Lipid Research, Washington University School \\ of Medicine, St. Louis, Missouri 63110, and ${ }^{6}$ Taipei Medical University, Taipei City, Taiwan 110
}

It has been postulated that the development of amyloid plaques in Alzheimer's disease (AD) may result from an imbalance between the generation and clearance of the amyloid- $\beta$ peptide $(\mathrm{A} \beta)$. Although familial $\mathrm{AD}$ appears to be caused by $\mathrm{A} \beta$ overproduction, sporadic $\mathrm{AD}$ (the most prevalent form) may result from impairment in clearance. Recent evidence suggests that several proteases may contribute to the degradation of $\mathrm{A} \beta$. Furthermore, astrocytes have recently been implicated as a potential cellular mediator of $\mathrm{A} \beta$ degradation. In this study, we examined the possibility that matrix metalloproteinases (MMPs), proteases known to be expressed and secreted by astrocytes, could play a role in extracellular $\mathrm{A} \beta$ degradation. We found that astrocytes surrounding amyloid plaques showed enhanced expression of MMP-2 and MMP-9 in aged amyloid precursor protein (APP)/presenilin 1 mice. Moreover, astrocyte-conditioned medium (ACM) degraded $\mathrm{A} \beta$, lowering levels and producing several fragments after incubation with synthetic human $\mathrm{A} \beta_{1-40}$ and $\mathrm{A} \beta_{1-42}$. This activity was attenuated with specific inhibitors of MMP-2 and -9, as well as in ACM derived from mmp-2 or -9 knock-out (K0) mice. In vivo, significant increases in the steady-state levels of $\mathrm{A} \beta$ were found in the brains of $m m p-2$ and $-9 \mathrm{KO}$ mice compared with wild-type controls. Furthermore, pharmacological inhibition of the MMPs with $\mathrm{N}$-[(2R)-2-(hydroxamidocarbonylmethyl)-4-methylpentanoyl]-Ltryptophan methylamide (GM 6001) increased brain interstitial fluid A $\beta$ levels and elimination of half-life in APPsw mice. These results suggest that MMP-2 and -9 may contribute to extracellular brain A $\beta$ clearance by promoting $\mathrm{A} \beta$ catabolism.

Key words: Alzheimer's disease; amyloid $\beta$ clearance; astrocytes; laser-capture microdissection; matrix metalloproteinases; microdialysis

\section{Introduction}

Alzheimer's disease (AD) is characterized by the abnormal accumulation of extracellular aggregated amyloid- $\beta$ peptide $(A \beta)$ in senile plaques within the brain. Spontaneous aggregation into amyloid fibrils appears to be concentration dependent; thus, mechanisms that regulate extracellular [brain interstitial fluid (ISF)] A $\beta$ levels may be important for amyloid plaque formation. Under normal physiological conditions, $A \beta$ exists in brain extracellular fluids (ISF and CSF) at relatively low concentrations (Selkoe, 1993; Vigo-Pelfrey et al., 1993; Saido, 1998). This steadystate level of $\mathrm{A} \beta$ is maintained by a balance between production and clearance (Saido, 1998). In general, genetic mutations in familial $\mathrm{AD}$ point to $\mathrm{A} \beta$ overproduction as a cause for disease (Tanzi et al., 1996); however, it has been suggested that the more prevalent sporadic form of the disease may be caused by impaired

Received May 16, 2006; revised Aug. 17, 2006; accepted Sept. 17, 2006.

This work was supported by United States Public Health Service Grants P41-RR00954, P60-DK20579, and P30DK56341 (J.T.), National Institutes of Health Grants AG13956 (D.M.H.), NS40525 (J.-M.L.), and NS48283 (J.-M.L.), and American Heart Association Grants 0460066 (J.-M.L.) and 0630209N (K.J.Y.).

Correspondence should be addressed to Dr. Jin-Moo Lee, Department of Neurology, Campus Box 8111, Washington University School of Medicine, 660 South Euclid Avenue, St. Louis, M0 63110. E-mail: leejm@neuro.wustl.edu.

DOI:10.1523/JNEUROSCI.2085-06.2006

Copyright $\odot 2006$ Society for Neuroscience 0270-6474/06/2610939-10\$15.00/0
$\mathrm{A} \beta$ clearance. Several major pathways for $\mathrm{A} \beta$ clearance have been investigated: receptor-mediated cellular uptake, blood-brain barrier transport (Shibata et al., 2000; Van Uden et al., 2002; Herz, 2003; Silverberg et al., 2003; Zlokovic, 2004), and direct proteolytic degradation (Saito et al., 2003).

Several $\mathrm{A} \beta$-degrading proteases have been identified by their ability to cleave $A \beta$, including neprilysin (NEP) (Iwata et al., 2001; Leissring et al., 2003; Marr et al., 2003), insulin-degrading enzyme (IDE) (Bennett et al., 2000; Kurochkin, 2001; Farris et al., 2003; Leissring et al., 2003), endothelin-converting enzyme (ECE) (Eckman et al., 2001, 2003), angiotensin-converting enzyme (ACE) (Hu et al., 2001), the plasminogen activators (Van Nostrand and Porter, 1999; Tucker et al., 2000), matrix metalloproteinase (MMP)-9 (Backstrom et al., 1996), and MMP-2 (Roher et al., 1994). Each protease appears to have distinguishing cleavage sites and generates characteristic $\mathrm{A} \beta$ fragments (Carson and Turner, 2002); however, only NEP, IDE, and ECE have been reported to influence $\mathrm{A} \beta$ levels in the brains of experimental animal models (Iwata et al., 2001; Eckman et al., 2003; Farris et al., 2003; Leissring et al., 2003; Marr et al., 2003). Although MMP-2 and -9 have been found to cleave A $\beta$ peptide at several sites (Roher et al., 1994; Backstrom et al., 1996), these MMPs have not been well studied with regard to their potential role in amyloid clearance in animal models. As candidate proteases for $\mathrm{A} \beta$ 
degradation, the MMPs are ideally situated to regulate extracellular $\mathrm{A} \beta$ levels, because they are secreted and activated in the extracellular compartment.

Activated astrocytes are found surrounding amyloid plaques in the $\mathrm{AD}$ brain and in amyloid precursor protein (APP) transgenic mice. Although their role in disease pathogenesis is poorly understood, recent evidence suggests that they may mediate $\mathrm{A} \beta$ degradation in the extracellular space (Akiyama et al., 2000; Wegiel et al., 2000; Wyss-Coray and Mucke, 2002; Vehmas et al., 2003) and may regulate amyloid plaque degradation (WyssCoray et al., 2003; Koistinaho et al., 2004). MMPs are expressed in astrocytes (Gottschall et al., 1995; Muir et al., 2002), and their activity is induced in the presence of $\mathrm{A} \beta$ (Deb and Gottschall, 1996; Deb et al., 2003). With accumulating evidence implicating proteases as key regulators of $A \beta$ metabolism, we investigated the possibility that MMPs could play a role in astrocyte-mediated $\mathrm{A} \beta$ degradation.

\section{Materials and Methods}

Experimental mice. Two different experimental AD animal models were used in this study. Hemizygous double-transgenic mice expressing both human APP (K670N:M671L) and human presenilin 1 (PS1) (M146L) (Holcomb et al., 1998) were purchased from Jackson Laboratory (Bar Harbor, ME). APPsw (Tg2576) mice, overexpressing APP695 with the Swedish AD mutations at positions 670/671 under control of the prion promoter, were a generous gift from Dr. Karen Hsiao-Ashe (Hsiao et al., 1996). Mmp-2 [C57BL6 background (Itoh et al., 1997)] and mmp-9 [SVEV129 background (Vu et al., 1998)] null mice were generous gifts of Dr. Shigeyoshi Itohara (RIKEN Brain Science Institute, Saitama, Japan) and Dr. Michael Shipley (Washington University School of Medicine at Barnes-Jewish Hospital, St. Louis, MO), respectively. All experimental protocols were approved by the Animal Studies Committee of Washington University.

Immunohistochemistry. APP/PS1 transgenic mice at age 12-18 months and age-matched wild-type mice $(n=5)$ were anesthetized with halothane. The brains were dissected out and snap frozen on dry ice. Coronal sections $(10 \mu \mathrm{m})$ were cryosectioned and mounted on gelatin-coated slides. The sections were permeabilized in PBS containing $0.3 \%$ Triton $\mathrm{X}-100$ (PBT) for $30 \mathrm{~min}$ at room temperature, followed by incubation with PBT containing $1 \%$ bovine serum albumin for $1 \mathrm{~h}$ at room temperature. A rabbit IgG labeling kit (Zenon Tricolor Rabbit IgG labeling Kit \#1; Molecular Probes, Eugene, OR) was used for triple-labeling experiments with the following antibodies: rabbit anti-MMP-2 polyclonal antibody (Chemicon, Temecula, CA), rabbit anti-MMP-9 polyclonal antibody (a gift from Dr. Robert Senior, Washington University School of Medicine at Barnes-Jewish Hospital, St. Louis, MO), and rabbit anti-glial fibrillary acidic protein (GFAP) polyclonal antibody (Sigma, St. Louis, MO). IgG labeling was performed according to the Zenon Complex Formation protocol and diluted in PBT to the desired working concentration. After incubation of the sections with the labeling complex in a humidified chamber for $1-2 \mathrm{~h}$ at room temperature, the sections were washed, mounted, and examined with confocal microscopy (Zeiss LSM, Oberkochen, Germany). A negative-control sample was processed with the same protocol, with the omission of the primary antibody, to assess nonspecific labeling. A positive control sample labeled by conventional secondary detection methods was included in pilot studies to confirm the specificity of the staining pattern of MMP-2 and -9 observed with the Zenon labeling method.

Laser-capture microdissection. Laser-capture microdissection (LCM) was performed as described previously (Burbach et al., 2004a,b). Mouse brains were dissected from 12- to 15-month-old APP/PS1 transgenic mice and age-matched wild-type mice $(n=5)$. Cryosections $(7 \mu \mathrm{m}$ thick) were cut and processed for immunostaining with a specific monoclonal antibody to GFAP (1:200; Sigma) and then dehydrated as described (Mills et al., 2002, 2003). GFAP-immunoreactive astrocytes were targeted for laser capture microdissection by using the PixCell II system (Arcturus, Mountain View, CA; 7.5- $\mu$ m-diameter laser spot) and Cap-
Sure HS LCM Caps (Arcturus). RNA was isolated from captured astrocytes with a PicoPure RNA Isolation Kit (Arcturus) with on-column DNase digestion. Integrity of the isolated RNA was determined with the RNA 6000 Pico Lab Chip (Agilent Technologies, Waldbronn, Germany) and then subjected to real-time quantitative PCR analysis for MMP-2 and -9 .

Astrocyte cultures. Meninges were removed from brains from neonatal mice (C57BL6; postnatal day 1), and the brains were collected in DMEM. The tissue was homogenized and incubated at $37^{\circ} \mathrm{C}$ for $15 \mathrm{~min}$ in HBSS containing $2.5 \mathrm{mg} / \mathrm{ml}$ trypsin (Sigma), $0.2 \mathrm{mg} / \mathrm{ml}$ EDTA, $1 \mathrm{mg} / \mathrm{ml}$ glucose, and $0.1 \mathrm{mg} / \mathrm{ml}$ bovine pancreatic DNase I. After digestion, cell suspensions in $10 \mathrm{ml}$ culture medium were plated on uncoated $100 \mathrm{~mm}$ dishes and incubated at $37^{\circ} \mathrm{C}$ for $2 \mathrm{~h}$; then, nonadherent cells were replated on six-well plates coated with poly-L-lysine. Culture medium was changed twice a week (Schwartz and Wilson, 1992). Neonatal astrocytes were also cultured from $m m p 2-/-$ and $+/+$ mice (C57BL6 background) and $m m p 9-/-$ and $+/+$ mice (SVEV129 background).

$A \beta$ preparation and $A \beta$ degradation in astrocyte-conditioned medium. Soluble $A \beta$ solution was freshly prepared as described (Stine et al., 2003). Synthetic human $\mathrm{A} \beta_{1-40}$ and $\mathrm{A} \beta_{1-42}$ (Bachem, Torrance, $\mathrm{CA}$ ) were first dissolved in dimethyl sulfoxide to a concentration of $5 \mathrm{~mm}$ and then diluted into Ham's F-12 to a final concentration of $50 \mu \mathrm{M}$.

Astrocytes grown to $90 \%$ confluence were washed, and serum-free medium (SFM) was added for another $24 \mathrm{~h}$. Collected astrocyteconditioned medium (ACM) was incubated with freshly-prepared synthetic human $\mathrm{A} \beta_{1-40}$ or $\mathrm{A} \beta_{1-42}(50 \mu \mathrm{M})$ at a final concentration of 2 $\mu \mathrm{g} / \mathrm{ml}$ at $37^{\circ} \mathrm{C}$ for $24 \mathrm{~h}$ (Qiu et al., 1997). Selective MMP inhibitors were added as follows: MMP-2 inhibitor (17 $\mu$; Calbiochem, La Jolla, CA) (Emonard et al., 1999), MMP-9 inhibitor (50 nM; Calbiochem) (Tamura et al., 1998), and GM6001 (100 $\mu \mathrm{M}$; Calbiochem) (Galardy et al., 1994). After digestion, samples were collected for further analysis.

ELISA to detect A $\beta$ levels. ACM, brain tissue lysates, and microdialysis samples were analyzed with a denaturing sandwich ELISA to measure $A \beta$ levels (Cirrito et al., 2003). For human $\mathrm{A} \beta$, C-terminal domain monoclonal antibodies specific for either $\mathrm{A} \beta_{1-40}(\mathrm{~m} 2 \mathrm{G} 3)$ or $\mathrm{A} \beta_{1-42}$ (m21F12) were used for capture, and biotinylated $\mathrm{N}$-terminal domain monoclonal antibodies (m3D6) were used for detection, followed by streptavidinhorseradish peroxidase-20 (Research Diagnostics, Flanders, NJ). Mouse $\mathrm{A} \beta_{1-40}$ and $\mathrm{A} \beta_{1-42}$ were captured with either m266 or m21F12 and detected with biotinylated $\mathrm{m} 2 \mathrm{G} 3$ or $\mathrm{m} 266$. Slow ELISA tetramethylbenzidine (Sigma) was used for colorimetric detection and analyzed on a BioTek (Winooski, VT) 600FL microtiter plate reader. $\mathrm{A} \beta_{1-40}$ and $\mathrm{A} \beta_{1-42}$ standard curves were generated from human or rodent $\mathrm{A} \beta$ peptide obtained from American Peptide (Sunnyvale, CA).

Tris-Tricine gel-Western blot. ACM samples were separated on a $16.5 \%$ Tricine SDS gel at $20 \mathrm{~mA}$ constant current for $3 \mathrm{~h}$ and transferred to polyvinylidene difluoride (PVDF) membrane (Bio-Rad, Hercules, CA) at $40 \mathrm{~V}$ overnight. Membranes were boiled for $10 \mathrm{~min}$ in PBS and then blocked overnight at $4{ }^{\circ} \mathrm{C}$ with $5 \%$ fat-free milk in Tris-buffered saline Tween-20. The blot was incubated with a primary antibody mixture consisting of mouse anti-4G8 (1:1000; Signet Laboratories, Dedham, MA), anti-3D6, anti-2G3, and anti-21F12 antibodies (1:1000), and then with a secondary antibody (anti-mouse conjugated with alkaline phosphatase) (Promega, Madison, WI) at room temperature for $1 \mathrm{~h}$ and developed with the AP Blot System (Promega) (Kawarabayashi et al., 2001).

For routine Western blot, total proteins were isolated from mouse brain tissue or ACM as reported previously (Yin et al., 2002). Samples were analyzed by $10-15 \%$ SDS-PAGE gel and transferred to PVDF membranes. The blot was incubated with various primary antibodies including rabbit anti-NEP (1:500; Chemicon), rabbit anti-IDE (1:500; EMD Bioscience, La Jolla, CA), mouse anti-MMP-2 (1;500; EMD Bioscience), goat anti-MMP-9 (1:1000; R \& D Systems, Minneapolis, MN), rabbit anti-ECE (1:500; R \& D Systems), rabbit anti-APP C-terminal fragments (1:500; Zymed Laboratories, San Francisco, CA), and mouse anti-actin antibody (1:200; Santa Cruz Biotechnology, Santa Cruz, CA). The membranes were then incubated with the appropriate secondary antibody (1:4000; anti-rabbit, anti-mouse, or anti-goat IgG conjugated with alka- 
line phosphatase; Promega) at room temperature for $1 \mathrm{~h}$. The color reaction was developed as described above.

Immunoprecipitation-mass spectrometry. ACM samples in radioimmunoprecipitation assay (RIPA) buffer and protease inhibitors were incubated overnight with an antibody mixture (4G8, 1:1000; Signet Laboratories; 3D6, 2G3, and 21F12; 1:1000). Protein G-Sepharose (25 $\mu \mathrm{l}$ of $50 \%$ slurry) was then added, and incubation continued for $3 \mathrm{~h}$. The Sepharose beads were then collected by centrifugation and washed sequentially with RIPA buffer and $25 \mathrm{~mm}$ ammonium bicarbonate, and $\mathrm{A} \beta$ was eluted with $100 \%$ formic acid. Matrix-assisted laser desorption ionization-time-of-flight (MALDI-TOF) mass spectra were acquired with a Voyager DE STR instrument (Applied Biosystems, Foster City, $\mathrm{CA}$ ) in linear mode. The matrix solution was saturated 3, 5-dimethoxy4-hydroxycinnamic acid in 50\% acetonitrile with $0.1 \%$ trifluoroacetic acid. An aliquot of matrix/sample $(1: 1, \mathrm{v} / \mathrm{v})$ was loaded onto the MALDI target plate and allowed to dry at room temperature. Internal standard insulin $[\mathrm{M}+\mathrm{H}]^{+}$and $[\mathrm{M}+2 \mathrm{H}]^{2+}$ ions were used to construct a two-point calibration line (Wang et al., 1996; Pype et al., 2003).

Extraction of $A \beta$ from mouse brains. Brains were removed from anesthetized $m m p-2$ or -9 knock-out (KO) mice and corresponding agematched wild-type controls after perfusion with cold saline. Cerebral cortex and hippocampus were dissected and snap frozen and then homogenized in $10 \mathrm{vol}$ of PBS $(\mathrm{w} / \mathrm{v})$ with protease inhibitor mixture (Sigma) in a Dounce homogenizer. After centrifugation $(16000 \times g$ for $1 \mathrm{~h}$ at $4^{\circ} \mathrm{C}$ ), the supernatant was collected (PBS-soluble fraction) for analysis of soluble $\mathrm{A} \beta$. The pellet was resuspended in $150-300 \mu \mathrm{l} 5 \mathrm{M}$ guanidine Tris buffer ( $50 \mathrm{~mm}$ Tris, $\mathrm{pH} 8.0,5 \mathrm{~m}$ guanidine) and rocked for $4 \mathrm{~h}$ at room temperature. After centrifugation $(16000 \times g$ for $30 \mathrm{~min}$ at $4^{\circ} \mathrm{C}$ ), the supernatant was collected (PBS-insoluble fraction) and used for analysis of insoluble $\mathrm{A} \beta$ (Kawarabayashi et al., 2001; Pype et al., 2003).

Construction of adeno-associated virus recombinant plasmids. Total RNA $(2 \mu \mathrm{g})$ isolated from HeLa cells with TRI reagent (Molecular Research Center, Cincinnati, OH) was reverse transcribed with $200 \mathrm{U}$ of Reverse Transcriptase (Promega) and $0.5 \mu \mathrm{g}$ of oligo $(\mathrm{dT})_{15}$ following the manufacturer's protocol. Primer sequences to amplify the human tissue inhibitor of metalloproteinase 1 (TIMP-1) cDNA were as follows: TIMP-1 forward, 5'-GAG ACA CCA GAG AAC CCA CCA TGG CC-3'; and TIMP-1 reverse, $5^{\prime}$-CAC TCC GGG CAG GAT TCA GGC TAT CT- $3^{\prime}$. PCR products were then cloned into pGEM-T easy vector (Promega) and sequenced. Fragments encoding TIMP-1 were subcloned into the multiple cloning site of the dephosphorylated adeno-associated virus vector (pAAV) with EcoRI. Astrocytes were transfected in six-well plates with $2 \mu \mathrm{g}$ of AAV recombinant TIMP-1 plasmid DNA by means of the calcium phosphate co-precipitation method. After $48 \mathrm{~h}$, culture supernatants were removed, and fresh serum-free DMEM was then added for incubation for another $24 \mathrm{~h}$ to collect ACM (Zolotukhin et al., 2002; Burger et al., 2004).

Real-time PCR. Real-time quantitative PCR was used to measure mRNA expression of MMP-2 and -9 as described previously (Yin et al., 2006). Total RNA from the mouse brain regions or microdissected astrocytes by laser beam was isolated with the RNeasy Mini Kit (Qiagen, Valencia, CA) or the PicoPure RNA Isolation Kit (Arcturus). Equal amounts of total RNA were reverse transcribed and then 1-10 ng of cDNA was subjected to PCR with the ABI Prism 7000 Sequence Detection System (Applied Biosystems) and SYBR Green PCR Master Mix (Applied Biosystems). The primers of the MMP genes were designed with Primer Express software (Applied Biosystems) as follows: MMP-2 (forward: $5^{\prime}$-gtcgcccctaaaacagacaa-3'; reverse: $5^{\prime}$-ggtctcgatggtgttctggt- $\left.3^{\prime}\right)$; $M M P-9$ (forward: $5^{\prime}$-cgtcgtgatccccacttact- $3^{\prime}$; reverse: $5^{\prime}$-aacacacagggtttgccttc- $3^{\prime}$ ); GFAP (forward: $5^{\prime}$-acatcgagatcgccacctac- $3^{\prime}$; reverse: $5^{\prime}$-tcacatcaccacgtccttgt- $3^{\prime}$ ); $18 S$ rRNA (forward: 5' -CATTCGAACGTCTGCCCTATC-3'; reverse: $5^{\prime}$-CCTGTGCCTTCCTTGGA-3'); and cyclophilin (forward: 5'-cgcttcccagatgagaacttca-3'; reverse: 5-actgtggttatgaagaactgtga- $\left.3^{\prime}\right)$. A standard amplification program was used $\left(1\right.$ cycle of $50^{\circ} \mathrm{C}$ for $2 \mathrm{~min}$; 1 cycle of $95^{\circ} \mathrm{C}$ for $10 \mathrm{~min}$; and 45 cycles of $95^{\circ} \mathrm{C}$ for $15 \mathrm{~s}$ and $60^{\circ} \mathrm{C}$ for $1 \mathrm{~min}$ ). All quantifications were normalized to cyclophilin or $18 \mathrm{~S}$ rRNA to account for variability in the initial concentration and quality of total RNA and in the conversion efficiency of the reverse-transcription reaction. The PCR experiments were repeated at least three times.
Gelatin-substrate zymography. Animals were perfused with saline, and cerebral cortex and hippocampus were removed and snap frozen at $-80^{\circ} \mathrm{C}$. Brain samples were then homogenized in $500 \mu \mathrm{l}$ of lysis buffer (50 mm Tris-HCl, pH 7.6, $150 \mathrm{~mm} \mathrm{NaCl,} 5 \mathrm{~mm} \mathrm{CaCl,} \mathrm{0.05 \%} \mathrm{Brij-35,}$ $0.02 \% \mathrm{NaN}_{3}$ ), and supernatant was collected after centrifugation. The brain supernatant or ACM was incubated with $50 \mu$ l of gelatin-Sepharose 4B (Pharmacia Biotech, Uppsala, Sweden) for $1 \mathrm{~h}$ with constant shaking. After centrifugation, the gelatin-Sepharose pellet was rinsed with $500 \mu \mathrm{l}$ of lysis buffer, and the solution was centrifuged again. The pellet was then incubated for $30 \mathrm{~min}$ with $50 \mu \mathrm{l}$ of elution buffer consisting of lysis buffer plus $10 \%$ dimethylsulfoxide (DMSO). Each $25 \mu$ l of eluted sample from the mouse brain region was mixed with $25 \mu \mathrm{l}$ of $2 \times$ nonreducing sample buffer $(0.125$ м Tris- $\mathrm{HCl}, 20 \%$ glycerol, $4 \%$ SDS, $0.003 \%$ bromophenol blue, $\mathrm{pH} 6.8$ ), loaded onto $7.5 \%$ SDS-PAGE containing $0.1 \%$ gelatin, and electrophoresed at $180 \mathrm{~V}$. Recombinant mouse MMP-2 and -9 (0.1-0.5 ng; EMD Bioscience) served as positive controls to identify the proMMP-2 (pro-) and active forms of MMP-2 and -9. The gel was incubated for $20 \mathrm{~h}$ at $37^{\circ} \mathrm{C}$ in buffer containing $21 \mathrm{~mm}$ Tris- $\mathrm{HCl}, 10 \mathrm{~mm} \mathrm{CaCl}_{2}$, and $0.04 \% \mathrm{NaN}_{3}$, pH 7.6, after two washes in $2.5 \%$ Triton X-100 for $20 \mathrm{~min}$. After incubation, the gel was stained for $1 \mathrm{~h}$ with $0.1 \%$ Coomassie Blue (diluted with $40 \%$ methanol and 10\% HAc) and destained until clear proteolytic bands appeared on a contrasting blue background (Zhang and Gottschall, 1997).

In vivo microdialysis. In vivo microdialysis was performed to assess brain ISF A $\beta$ levels in the hippocampus of 3-month-old APPsw transgenic mice as described previously (Cirrito et al., 2003, 2005). Under isoflurane volatile anesthetic, guide cannulas (BR-style; Bioanalytical Systems, Indianapolis, IN) were cemented into the left hippocampus (bregma: $-3.1 \mathrm{~mm}, 2.5 \mathrm{~mm}$ lateral to midline, and $1.2 \mathrm{~mm}$ below dura at a $12^{\circ}$ angle). Two millimeter microdialysis probes were inserted through the guides so that the membrane was contained entirely within the hippocampus (BR-2, $38 \mathrm{kDa}$ MWCO membrane; Bioanalytical Systems). The microdialysis perfusion buffer was artificial CSF containing $0.15 \%$ bovine serum albumin that was filtered through a $0.1 \mu \mathrm{M}$ membrane. An initial $6 \mathrm{~h}$ recovery period elapsed after guide implantation and probe insertion to allow for tissue recovery, followed by collection of microdialysis samples for $10 \mathrm{~h}$ at hourly intervals at a flow rate of $1.5 \mu \mathrm{l} / \mathrm{min}$ to establish basal $\mathrm{A} \beta$ levels in ISF. $N$-[(2R)-2-(hydroxamidocarbonylmethyl)-4methylpentanoyl]-L-tryptophan methylamide(GM6001; $250 \mu \mathrm{M})$ or vehicle $(0.05 \% \mathrm{DMSO})$ was infused directly into the hippocampus with reverse microdialysis, and samples were collected for an additional $14 \mathrm{~h}$. A $\beta$ was measured by ELISA at the completion of each experiment and expressed as the percentage of basal level for each mouse. The basal level was defined as the mean concentration for $10 \mathrm{~h}$ before treatment with GM6001.

A $\beta$ elimination half-life in ISF. ISF A $\beta$ elimination half-life was determined as described previously (Cirrito et al., 2003, 2005). Briefly, animals were implanted with microdialysis probes and allowed to recover for $6 \mathrm{~h}$ with normal perfusion buffer. Subsequently, $250 \mu \mathrm{M}$ GM6001 or vehicle ( $0.05 \%$ DMSO) was added to the microdialysis perfusion buffer. Animals were treated for $12 \mathrm{~h}$ via reverse microdialysis (to allow ISF A $\beta$ levels to reach a new steady state) and then injected subcutaneously with LY411575 [N2-[(2S)-2-(3,5-difluorophenyl)-2-hydroxyethanoyl]N1-[(7S)-5-methyl-6-oxo-6,7-dihydro-5H-dibenzo[b,d]azepin-7-yl]L-alaninamide] (3 mg/kg in corn oil), a blood-brain barrier-permeable $\gamma$-secretase inhibitor. Samples were collected at $30 \mathrm{~min}$ increments and assayed for $\mathrm{A} \beta_{1-\mathrm{x}}$ by ELISA.

To determine $A \beta$ half-life, time points between drug delivery and maximal A $\beta$ suppression were analyzed. For first-order processes, the elimination rate of a molecule from the body is directly related to the slope of the semi-log plot of concentration versus time as follows: $a=$ $-K_{e} / 2.3$, where $a$ represents the slope, and $K_{e}$ represents the elimination rate constant. The half-life $\left(t_{1 / 2}\right)$ of a molecule is the time necessary for the concentration to decrease by $50 \%$. By definition of a first-order process, the half-life remains constant regardless of molecule concentration. The half-life can be expressed in terms of the elimination rate constant as follows: $t_{1 / 2}=0.693 / K_{e}$.

Quantitative and statistical analysis. Quantitative data were expressed as mean \pm SD values. Differences among groups were analyzed statistically by one-way ANOVA followed by Bonferroni's post hoc $t$ test. Com- 

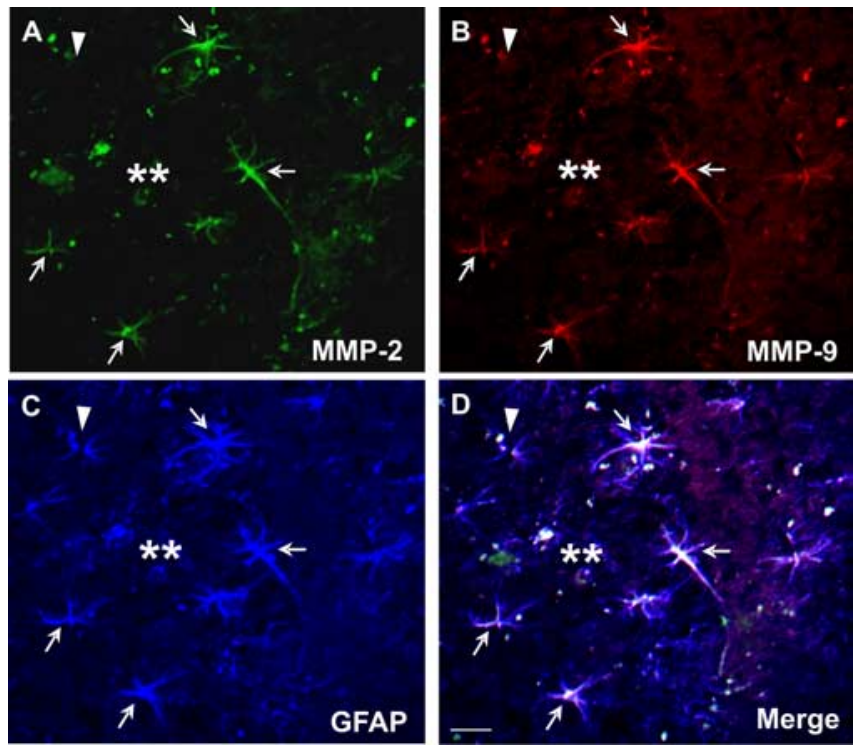

Figure 1. MMP-2 and -9 immunoreactivity is selectively increased in activated astrocytes surrounding amyloid plaques in aged APP/PS1 mice. MMP-2 (A) or MMP-9 (B) immunoreactive cells (arrow) were prominent in cells surrounding $A \beta$ deposits in the cortex or hippocampus of aged APP/PS1 mice. MMP-2 (A) and MMP-9 (B) immunoreactivity colocalized to GFAP-positive cells ( $\boldsymbol{C}$ ) showing morphological characteristics of reactive astrocytes ( $\boldsymbol{D}$, merged). Arrows indicate triple-labeled astrocytes with expression of MMP-2 and -9; arrowhead indicates a GFAPpositive astrocyte that is not immunoreactive to MMP-2 or -9; double asterisks indicate amyloid plaque. Scale bar, $10 \mu \mathrm{m}$.

parison between two experimental groups was based on the two-tailed $t$ test; $p<0.05$ was considered significant.

\section{Results}

Activated astrocytes surrounding amyloid plaques express MMP-2 and -9 in aged APP/PS1 mice

Previous reports have suggested that MMP-2 and -9 are capable of degrading A $\beta$ in vitro (Roher et al., 1994; Backstrom et al., 1996). To explore the possibility that these proteases were involved in $\mathrm{A} \beta$ degradation in vivo, we examined the cellular distribution of MMP-2 and -9 in 12- to 18-month-old APP/PS1 mice. Compared with age-matched wild-type controls, MMP-2 and -9 immunoreactivity was increased in the cerebral cortex and hippocampus of APP/PS1 mice, most prominently in GFAPpositive astrocytes surrounding amyloid plaques (Fig. 1). Moreover, both MMP-2 and -9 immunoreactivity colocalized to the same astrocytes, which appeared reactive by virtue of their hypertrophic cell bodies and prominent GFAP immunostaining (Fig. 1). MMP-2 and -9 appeared to be expressed primarily in astrocytes surrounding amyloid plaques, because GFAP-positive astrocytes distant from plaques did not show MMP-2 and -9 immunoreactivity.

To quantify these changes with real-time PCR or Western blotting, we examined whole-brain extracts from aged APP/PS1 mice, but these extracts did not reveal significant changes in levels of MMP-2 or -9 compared with control mice (data not shown). Therefore, we examined the expression of these MMPs selectively in astrocytes with LCM. GFAP immunoreactive astrocytes were target-captured by laser from sections prepared from aged wildtype and APP/PS1 mice (Fig. 2A). In sections from APP/PS1 mice, astrocytes surrounding amyloid plaques were captured separately from astrocytes distant from amyloid plaques. Extracted RNA quality was examined with picochip electropherograms that showed clear $18 \mathrm{~S}$ and $28 \mathrm{~S}$ rRNA peaks indicating high
RNA quality (Fig. 2B). Accurate capture of astrocytes was confirmed by GFAP quantitative RT-PCR, which revealed an 18-fold enrichment of GFAP mRNA compared with neighboring nonGFAP laser-captured cells (Fig. 2C). Quantitative RT-PCR of this preparation showed a dramatic increase in both MMP-2 and -9 mRNA in astrocytes surrounding amyloid plaques in aged APP/ PS1 transgenic mice compared with astrocytes distant from amyloid plaques, as well as astrocytes in age-matched wild-type controls (Fig. 2D).

\section{MMPs secreted by astrocytes degrade soluble $\mathbf{A} \boldsymbol{\beta}$}

The increased expression of MMPs in astrocytes surrounding amyloid plaques in APP/PS1 transgenic mice raises the possibility that MMPs in astrocytes may be associated with local $A \beta$ degradation and clearance. To assess this possibility, we examined A $\beta$ degrading activity in ACM to explore the contribution of MMPs to $\mathrm{A} \beta$ degradation. $\mathrm{ACM}$ was incubated with freshly prepared synthetic human $\mathrm{A} \beta_{1-40}$ or $\mathrm{A} \beta_{1-42}$ for $24 \mathrm{~h}$ at $37^{\circ} \mathrm{C}$. $\mathrm{A} \beta$ levels were then measured by ELISA (Fig. $3 A$ ) or by Tris-Tricine gelWestern blotting (Fig. $3 B$ ), and fragments were analyzed by MALDI-TOF mass spectrometry (MS) (Fig. 3C). Incubation of $\mathrm{A} \beta$ with $\mathrm{ACM}$ resulted in a significant decline in $\mathrm{A} \beta$ levels and caused the appearance of several $A \beta$ fragments, including 1-20, $1-30$, and 1-34, that are characteristic of MMP cleavage (Roher et al., 1994; Backstrom et al., 1996). Fragments generated by incubating ACM with $\mathrm{A} \beta_{1-40}$ were similar to those generated with $\mathrm{A} \beta_{1-42}$ (Fig. $3 C$ ). SFM alone had no $\mathrm{A} \beta$-degrading activity (Fig. $3 C$ ).

To further explore the contribution of MMPs to $A \beta$ degradation in ACM, we incubated ACM with freshly prepared synthetic human $\mathrm{A} \beta$ for $24 \mathrm{~h}$ at $37^{\circ} \mathrm{C}$ in the presence or absence of specific MMP-2 or -9 inhibitors or a broad-spectrum MMP inhibitor (GM6001). As shown in Figure $4 A, \mathrm{~A} \beta$-degrading activity in ACM was attenuated with all of these MMP inhibitors. Furthermore, inhibition by GM6001 was greater than the selective inhibitors alone, suggesting an additive effect of this broad spectrum inhibitor. A $\beta$-degrading activity was also significantly inhibited in astrocytes derived from mice with gene deletion of $m m p-2$ or -9 in comparison with astrocytes from their corresponding wildtype controls (Fig. $4 B$ ). We also performed MALDI-TOF MS on $\mathrm{A} \beta$ digestion with MMP- 2 and $-9 \mathrm{KO}$ astrocytes. The $\mathrm{A} \beta$ fragments were not changed by the gene deletions (data no shown). In addition, viral gene transfer of TIMP-1, an endogenous inhibitor of MMPs, into astrocytes also inhibited $\mathrm{A} \beta$-degrading activity (Fig. 4C,D). Consistent with these findings, ACM was found to have gelatinolytic activity migrating at identical MWs to recombinant mouse MMP-9 and -2 (both active and inactive forms) (Fig. $4 E$ ). These findings suggest the involvement of MMPs in the $A \beta$-degrading activity in ACM. Inhibition of MMPs with GM6001 did not completely block $A \beta$-degrading activity, suggesting the existence of other $A \beta$-degrading proteases in ACM. Western blot analysis of ACM failed to detect NEP, ECE, or IDE (see supplemental data on-line, available at www.jneurosci. org as supplemental material), suggesting that other as-yetunidentified proteases may also contribute to astrocyte-mediated A $\beta$ degradation.

\section{MMP-2 and -9 mediate brain A $\boldsymbol{\beta}$ catabolism in mice}

To more precisely assess the physiological role of MMP-2 and -9 in $\mathrm{A} \beta$ catabolism in vivo, we examined steady-state $\mathrm{A} \beta$ levels in the brains of $m m p-2$ and $-9 \mathrm{KO}$ mice compared with controls. As shown in Figure 5, significant increases in the levels of both $\mathrm{A} \beta_{1-40}$ and $\mathrm{A} \beta_{1-42}$ were found in the PBS-soluble fraction from cortex and hippocampus of $m m p-2$ null mice compared with 
A

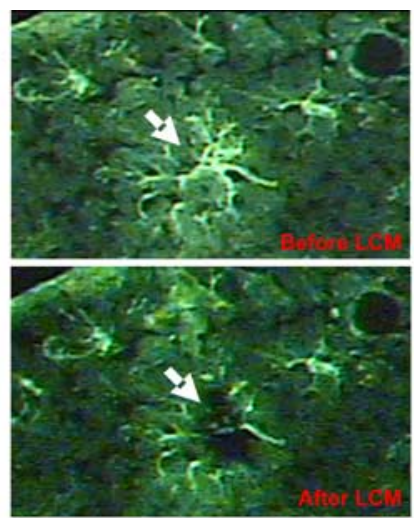

C

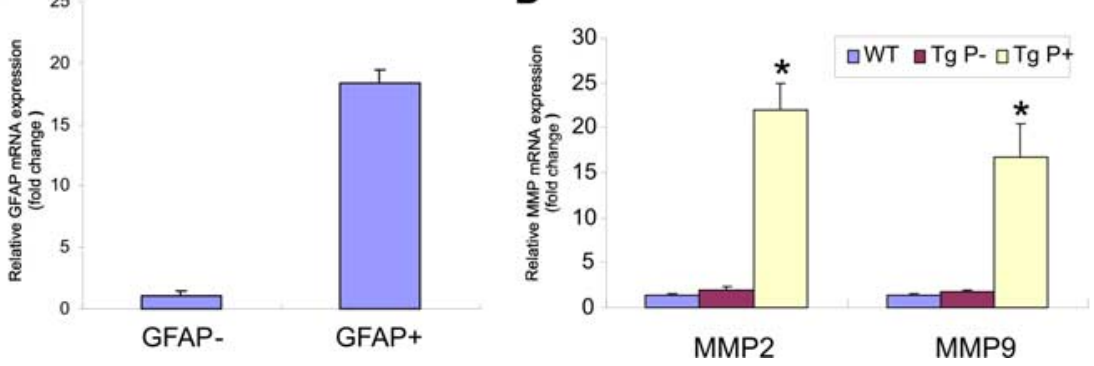

Figure 2. MMP-2 and -9 mRNA levels are elevated in astrocytes surrounding amyloid plaques in aged APP/PS1 mice. $\boldsymbol{A}$, Representative photomicrograph of GFAP-immunostained astrocytes in the cerebral cortex before and after laser capture microdissection. $\boldsymbol{B}$, RNA electropherogram from microdissected astrocytes shows distinct 185 and 285 rRNA peaks indicating high RNA quality. $C$, Relative quantification of GFAP mRNA by real-time PCR revealed an 18-fold increase in GFAP-positive astrocytes in comparison with GFAP-negative neighboring cells, suggesting excellent enrichment of astrocyte-specific RNA. D, Real-time PCR quantification revealed significant increases in both MMP-2 and -9 in astrocytes surrounding amyloid plaques (Tg P + ) compared with astrocytes distant from amyloid plaques ( $\mathrm{Tg} \mathrm{P}-$ ) and astrocytes from control mice (WT). ${ }^{*} p<0.05$; significant difference between wild-type and APP/PS1 astrocytes $(n=3)$. Error bars indicate mean \pm SD.

age-matched controls. In mice with an $m m p$-9 gene deletion, only $\mathrm{A} \beta_{1-42}$ levels were significantly increased in the PBS-soluble fraction; however, in the PBS-insoluble fraction (extracted with $5 \mathrm{M}$ guanidine), no changes in $A \beta$ levels were observed (Fig. 5). To assess whether this increase in $\mathrm{A} \beta$ was a result of decreased clearance (vs increased production) of $\mathrm{A} \beta$, the C-terminal fragment of the amyloid precursor protein was also measured by Western blot. No difference in C-terminal fragment was detected in $m m p-2$ or -9 null mice compared with their wild-type controls (data not shown), suggesting that the increased $A \beta$ levels were caused by a decrease in $A \beta$ proteolysis by the MMPs. As assessed by Western blotting and RT-PCR, $m m p-2$ and -9 gene deletion did not alter the levels of other $A \beta$-degrading proteases (NEP, IDE, and ECE) compared with their wild-type controls (data not shown), indicating that compensatory alterations in other known $\mathrm{A} \beta$-degrading proteases did not occur.

$M m p$-2 gene deletion resulted in a greater increase in brain $\mathrm{A} \beta$ levels compared with $m m p-9$ gene deletion, possibly suggesting a more important role for MMP- 2 in $\mathrm{A} \beta$ catabolism, at least in disease-freed mice. To further understand this difference in activity, we measured mRNA and gelatinolytic activity of MMP-2 and -9 in the brains of wild-type mice. MMP-2 mRNA was fourto sixfold higher than that of MMP-9 in mouse cortex and hippocampus (Fig. $6 \mathrm{~A}$ ). In agreement with this difference in expression, MMP-2 gelatinolytic activity was significantly higher than that of MMP-9 in these brain regions (Fig. 6B). This is also consistent with the constitutive expression of MMP-2 versus induction of MMP-9 under pathological conditions.

Because MMP-2 and -9 are secreted and activated in the ex- tracellular space (Yong et al., 1998; Van den Steen et al., 2002), their activity would be expected to influence extracellular levels of $A \beta$. In addition, the combined inhibition of the MMPs might be expected to have a greater affect on $A \beta$ clearance. To assess these possibilities in vivo, we measured $A \beta$ levels in the hippocampal ISF of APPsw mice with microdialysis (Cirrito et al., 2003, 2005) combined with pharmacological inhibition of the MMPs with GM6001. APPsw mice were used for microdialysis studies because ISF A $\beta$ levels can be measured serially every $30 \mathrm{~min}$ (Cirrito et al., 2003, 2005). As shown in Figure $7 A$, direct infusion of GM6001 into the hippocampus via reverse microdialysis resulted in an increase in endogenous $A \beta$ levels, reaching $\sim 150 \%$ of levels found in vehicle-treated mice after $6 \mathrm{~h}$ of treatment $\left({ }^{*} p<0.05 ; n=6-7\right.$ per group). The elimination half-life of $\mathrm{A} \beta$ can be determined by inhibiting $A \beta$ production with the potent $\gamma$-secretase inhibitor LY411575 (Fig. $7 B, C)$. In the presence of GM6001, the half-life of $\mathrm{A} \beta$ was increased by almost $50 \%$ compared with vehicle-treated animals ( $p=0.0079 ; n=5$ per group $)$, showing a direct role for MMPs in the degradation and clearance of ISF $A \beta$ in vivo.

\section{Discussion}

In this study we have shown that MMP-2 and -9 play a significant role in brain $\mathrm{A} \beta$ degradation and clearance. Their role in $\mathrm{A} \beta$ metabolism in vivo is suggested by the upregulation of these proteases (as shown by immunohistochemistry and laser-captured mRNA levels) in activated astrocytes surrounding amyloid plaques in aged APP/PS1 transgenic mice. That astrocytes secrete MMP-2 and - 9 was confirmed in conditioned medium experiments, where $\mathrm{A} \beta$ degrading activity was attenuated by inhibiting these proteases pharmacologically as well as by genetic and molecular approaches. Evidence that MMP- 2 and -9 degrade $A \beta$ in vivo was provided by gene deletion of these proteases that resulted in an increase in the steady-state levels of PBS-soluble murine $A \beta$ in brain. Interestingly, the PBS-insoluble $\mathrm{A} \beta$ fraction was unchanged by $m m p-2$ or -9 gene deletion, consistent with the fact that these proteases are active only in the extracellular compartment. Taking advantage of this fact, we specifically examined brain ISF A $\beta$ levels by using microdialysis before and after MMP inhibition with the broad spectrum inhibitor GM6001. The combined pharmacological inhibition of the MMPs acutely increased ISF $A \beta$ concentrations by $50 \%$. Furthermore, the $A \beta$ elimination half-life in ISF was extended by GM6001 by 50\%. These results suggest that MMP-2 and -9 play a role in the degradation and clearance of extracellular $\mathrm{A} \beta$ in the brain in vivo.

The matrix metalloproteinases are a family of 23 zincdependent endoproteases that are capable of degrading virtually all proteins in the extracellular matrix (Nagase et al., 1999; Woessner, 1999). The gelatinase subfamily, composed of MMP-2 and -9 , is initially expressed as inactive pro-enzymes and cleaved into active forms after cellular release (Van den Steen et al., 2002); 


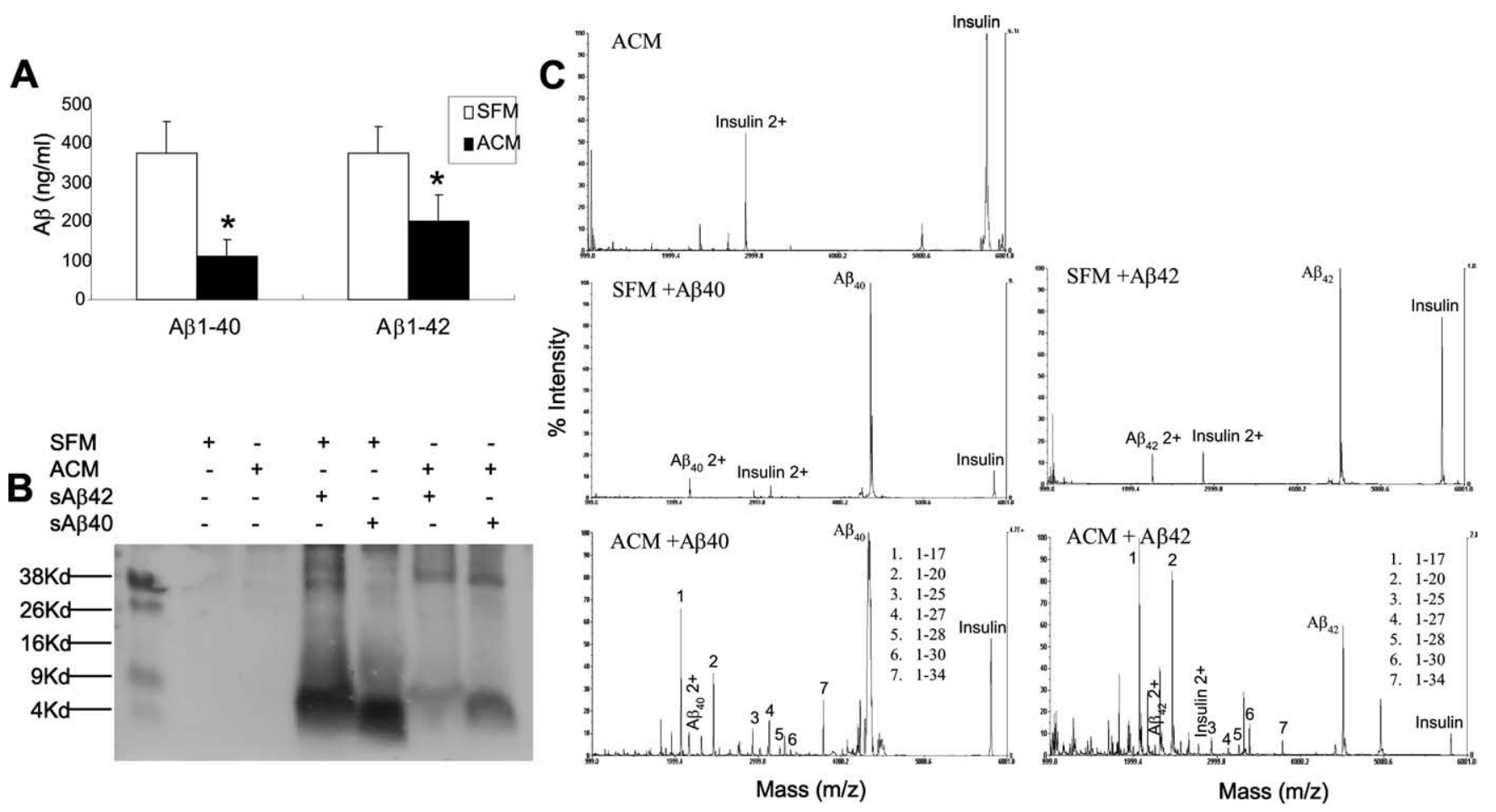

Figure 3. Astrocytes secrete $A \beta$-degrading activity in vitro producing characteristic $A \beta$ fragments. Freshly prepared synthetic human $A \beta_{1-40}$ or $A \beta_{1-42}$ was added to SFM or to SFM that had been conditioned by incubation with astrocytes for $24 \mathrm{~h}(\mathrm{ACM})$. The mixture was then incubated for $24 \mathrm{~h}$ at $37^{\circ} \mathrm{C}$, and residual $\mathrm{A} \beta$ was measured by ELISA (A) (expressed as mean $\pm S D$ ) or analyzed by Tris-Tricine-Western blotting $(\boldsymbol{B})$. Non-degraded $A \beta$ and its proteolytic fragments in the incubation mixtures were also analyzed by MALDI-TOF MS (C). Incubation with ACM significantly decreased $A \beta$ levels as measured by ELISA $(\boldsymbol{A})$ and immunoblotting $(\boldsymbol{B})$ and generated several $A \beta$ fragments detected by MALDI-TOF MS relative to insulin (internal standard) $(\boldsymbol{C})$ that have been shown previously to arise from $A \beta$ digestion with MMP-2 or -9 . No significant differences in detected fragments were seen in digestions with $A \beta_{1-40}$ compared with $A \beta_{1-42} \cdot{ }^{*} p<0.05$; significant difference between ACM and SFM.

this property places these proteases in a unique position to regulate levels of substrates in the extracellular space. Previous studies have shown that MMP-2 and -9 are capable of degrading synthetic or $\mathrm{AD}$ brain-derived $\mathrm{A} \beta_{1-40}$ in vitro (Roher et al., 1994; Backstrom et al., 1996). Furthermore, MMP-2 and -9 are expressed and secreted by astrocytes (Gottschall et al., 1995; Muir et al., 2002) and induced in the presence of $A \beta$ (Deb and Gottschall, 1996; Deb et al., 2003). Consistent with these studies, we have shown that the expression of MMP-2 and -9 is increased in astrocytes surrounding amyloid plaques in aged APP/PS1 mice.

The activation and accumulation of astrocytes around amyloid plaques is a pathological hallmark of AD (Akiyama et al., 2000; Wegiel et al., 2000; Wyss-Coray and Mucke, 2002; Vehmas et al., 2003). Although the precise role of these reactive astrocytes in disease pathogenesis is unclear, recent evidence suggests that astrocytes may contribute to the degradation and clearance of amyloid plaques (WyssCoray et al., 2003; Koistinaho et al., 2004). In the present study, we have observed that astrocytes secrete MMP-2 and -9 and that $\mathrm{ACM}$ can degrade $\mathrm{A} \beta$ to produce sev-
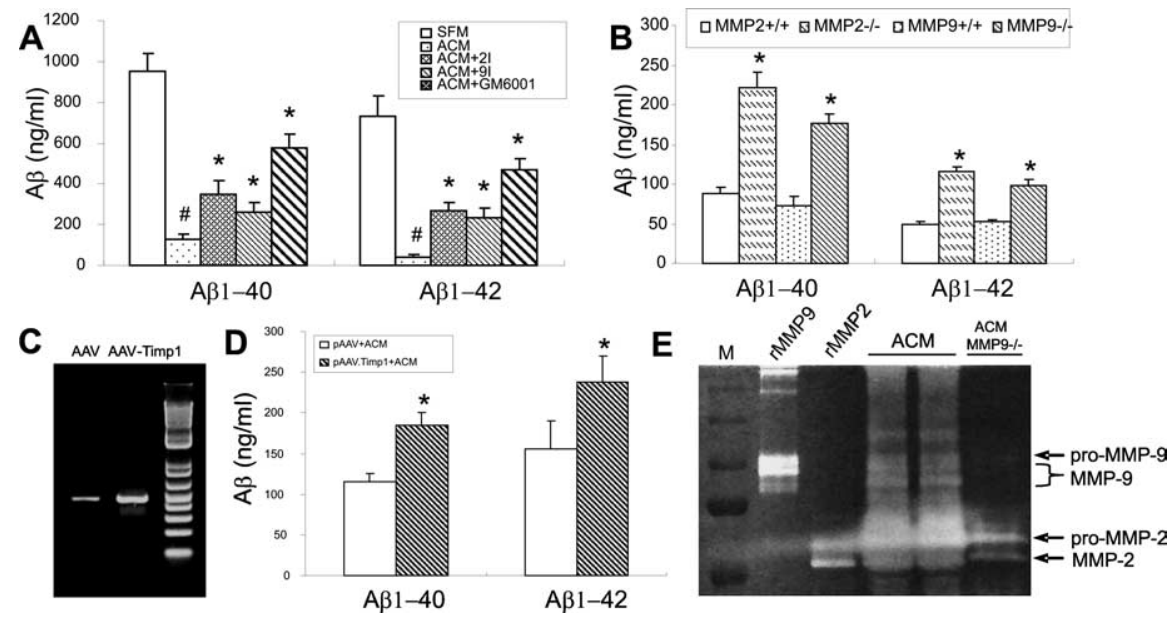

Figure 4. $A \beta$-degrading activity in ACM is mediated in part by MMP-2 and $-9 . A$, Synthetic human $A \beta_{1-40}$ or $A \beta_{1-42}$ was incubated with $A C M$ for $24 \mathrm{~h}$ at $37^{\circ} \mathrm{C}$ in the presence or absence of MMP-2 inhibitor, MMP-9 inhibitor, or the broad-spectrum MMP inhibitor GM6001. $A \beta$ was then measured by ELISA. $A \beta$-degrading activity in $A C M$ was attenuated by inhibitors of MMP- 2 and -9 . Inhibition by GM6001 was twice the magnitude of MMP-2 or -9 inhibitors alone. $B, A \beta$-degrading activity in ACM derived from mmp-2 or -9 gene deletion mice was significantly decreased compared with ACM from their corresponding wild-type controls. $C$, Gel electrophoresis shows increased expression of TIMP-1 (above basal levels) in AAV-TIMP-1-tranduced compared with AAVtransduced astrocytes. D, TIMP-1 viral gene transfer reduced $A \beta$-degrading activity compared with the AAV vector-infected controls. $E, A C M$ isolated from neonatal astrocytes was analyzed with gelatin zymography revealing several bands of gelatinolytic activity corresponding to pro- and active forms of MMP-9 and - 2. ACM from mmp9-/ - (ACM MMP9- - - ) lacks the three bands of activity observed in the rMMP9 and ACM lanes $(\boldsymbol{E})$. ${ }^{\#} p<0.05$; significant differences between SFM. ${ }^{*} p<0.05$; significant difference among ACM $(\boldsymbol{A})$, WT $(\boldsymbol{B})$, or pAAV + ACM (D) groups. rMMP9, Recombinant mouse MMP-9; rMMP2, recombinant mouse MMP-2. Error bars indicate SD. 
MMP2 KO
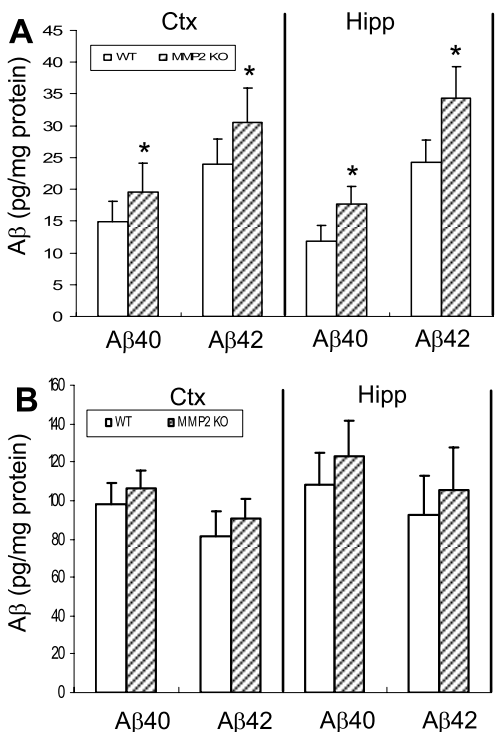

MMP9 KO
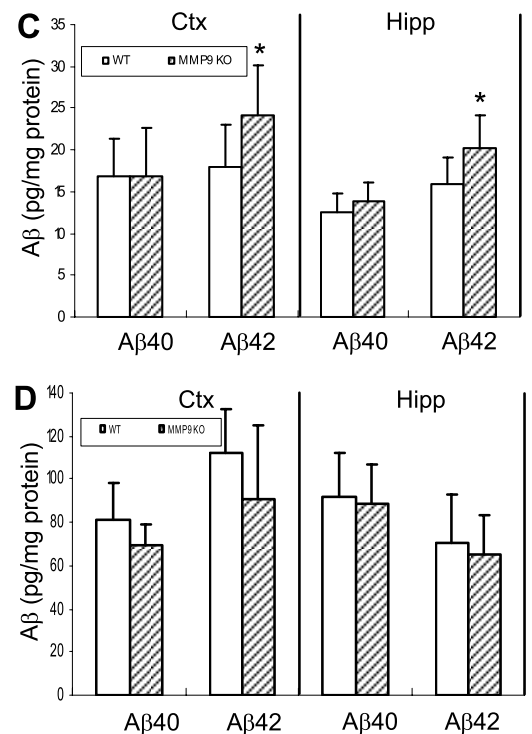

Figure 5. $\quad m m p-2$ and -9 gene deletion alters steady-state $A \beta$ levels in mouse brain. PBS-soluble and -insoluble $A \beta$ were sequentially extracted from cerebral cortex and hippocampus of $m m p-2 \mathrm{~K} 0, m m p-9 \mathrm{~K} 0$, and corresponding wild-type mice. $m m p-2$ K0 mice showed higher levels of endogenous $A \beta_{1-40}$ and $A \beta_{1-42}$ in the PBS-extractable fraction of cerebral cortex and hippocampus compared with wild-type controls $(A)$. mmp-9 K0 mice also exhibited a higher level of endogenous $A \beta_{1-42}$ in the same fraction (C); however, $A \beta$ levels in the PBS-insoluble fraction from the K0 mice were unchanged compared with controls $(\boldsymbol{B}, \boldsymbol{D})$. PBS-sol, PBS-soluble fraction; PBS-insol, PBS-insoluble fraction; Ctx, cerebral cortex; Hipp, hippocampus. The concentration of A $\beta$ is expressed as mean $\pm S D$. ${ }^{*} p<0.05$; significant difference compared with wild-type $(n=8-12)$.

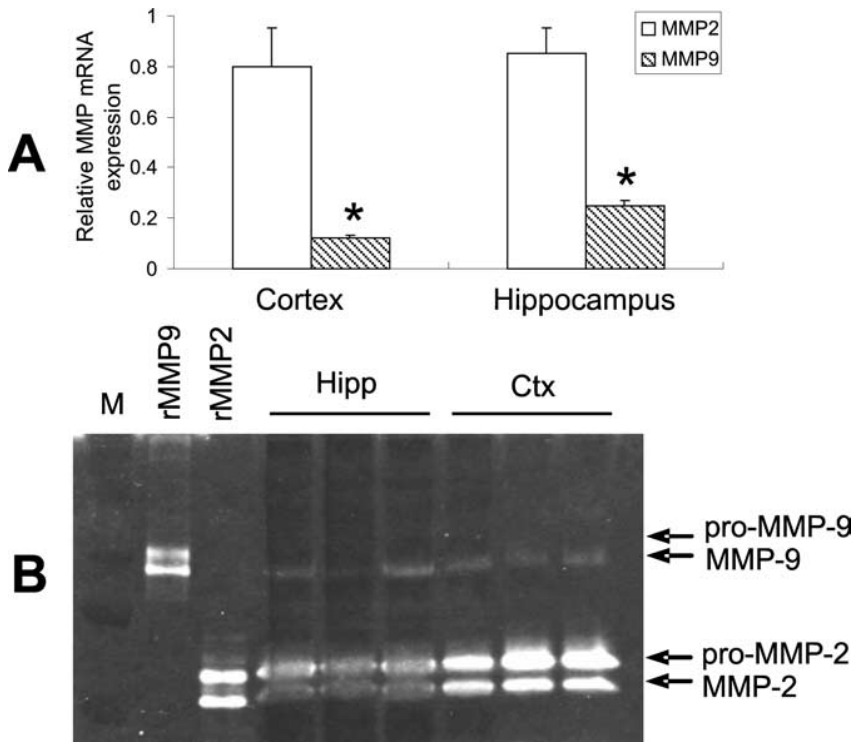

Figure 6. Basal expression of MMP- 2 and -9 in mouse brain. $A$, MMP- 2 and -9 mRNA expression was quantified with real-time PCR. MMP-2 mRNA levels were four- to sixfold higher than that of MMP-9 in the indicated brain regions. $\boldsymbol{B}$, Gelatin zymography revealed a similar profile of gelatinolytic activity. Data are expressed as mean $\pm S D .{ }^{*} p<0.05$, compared with MMP-2 expression ( $n=3$ ). rMMP9, Mouse recombinant MMP-9; rMMP2, mouse recombinant MMP-2.

eral fragments, some of which are known to be generated by MMP degradation $\left(\mathrm{A} \beta_{1-30}\right.$ and $\left.\mathrm{A} \beta_{1-34}\right)$. Furthermore, we have shown that this $A \beta$-degrading activity is attenuated by specific MMP-2 or -9 inhibitors, and a greater effect was observed with the broad-spectrum MMP inhibitor GM6001. These results were confirmed by experiments with ACM derived from $m m p-2$ and $-9 \mathrm{KO}$ mice, which had decreased $\mathrm{A} \beta$-degrading activity compared with wild-type ACM. Furthermore, viral gene transfer of the endogenous MMP inhibitor (TIMP-1) into astrocytes also inhibited $\mathrm{A} \beta$-degrading activity. It should be noted that GM6001 did not completely inhibit $A \beta$-degrading activity and that $\mathrm{A} \beta$ fragments generated by $\mathrm{ACM}$ digestion suggest the existence of other as yet unidentified proteases in ACM that may also possess this activity. Western blot analysis of ACM revealed the presence of MMP-2 and -9 but not NEP, IDE, or ECE (data not shown). Therefore, our data suggest that MMP- 2 and -9 contribute to $A \beta$ degrading activity in ACM.

The A $\beta$-degrading activities of MMP-2 and -9 in the extracellular space was also evident in vivo in the mouse brain. Gene deletion of $m m p-2$ or -9 resulted in increased steady-state levels of endogenous murine $\mathrm{A} \beta$ only in the PBS-soluble fraction; levels in the PBS-insoluble fraction were unchanged compared with wild-type controls. Furthermore, infusion of GM6001 into the hippocampus of APPsw mice resulted in a $50 \%$ increase in ISF $A \beta$ levels and a $50 \%$ increase in the ISF $A \beta$ elimination half-life. These results show that MMP-2 and - 9 mediate brain $\mathrm{A} \beta$ catabolism in the extracellular compartment, consistent with their site of action. The other $\mathrm{A} \beta$-degrading proteases have distinct cellular localizations that likely influence their activities as well. NEP is a zinc metallopeptidase that is localized on neuronal membranes at the synapse (Barnes et al., 1992). IDE, of the inverzincin family of zinc proteinases, is located primarily in the cytosol (Duckworth et al., 1998) but also in the plasma membrane (Seta and Roth, 1997; Vekrellis et al., 2000) and is secreted by microglial cells (Qiu et al., 1998). ECE exists as four different alternatively spliced isoforms distributed differentially between the cell surface and the cytosol (Schweizer et al., 1997).

Our studies have focused primarily on disease-free mice (i.e., mice without plaque pathology) and thus might represent $\mathrm{A} \beta$ metabolism under normal physiological conditions (premorbid period). Under these conditions, gene deletion of $m m p-2$ appeared to have a greater effect on brain $A \beta$ levels compared with $m m p-9$ gene deletion. Consistent with these data, the expression and activity of MMP-2 was greater than that of MMP-9 in wildtype mice. MMP-2 is considered a constitutively expressed MMP, whereas MMP-9 is expressed at low levels under normal conditions (Gottschall et al., 1995; Yong et al., 1998; Planas et al., 2001) but is induced under pathological conditions, such as cerebral ischemia and neurodegeneration (Aoki et al., 2002; Lo et al., 2002; Lee et al., 2003). It is possible that under pathological conditions, MMP-9 may play a greater role in A $\beta$ clearance; its expression is certainly increased in astrocytes surrounding amyloid plaques in aged APPsw mice. It is likely that plaque pathogenesis results from a complex interplay between $A \beta$ overproduction and decreased clearance, and the role of MMPs in this process is unclear. Additional experiments will be needed to determine whether MMPs play a role in the pathogenesis of amyloid plaque pathology. 

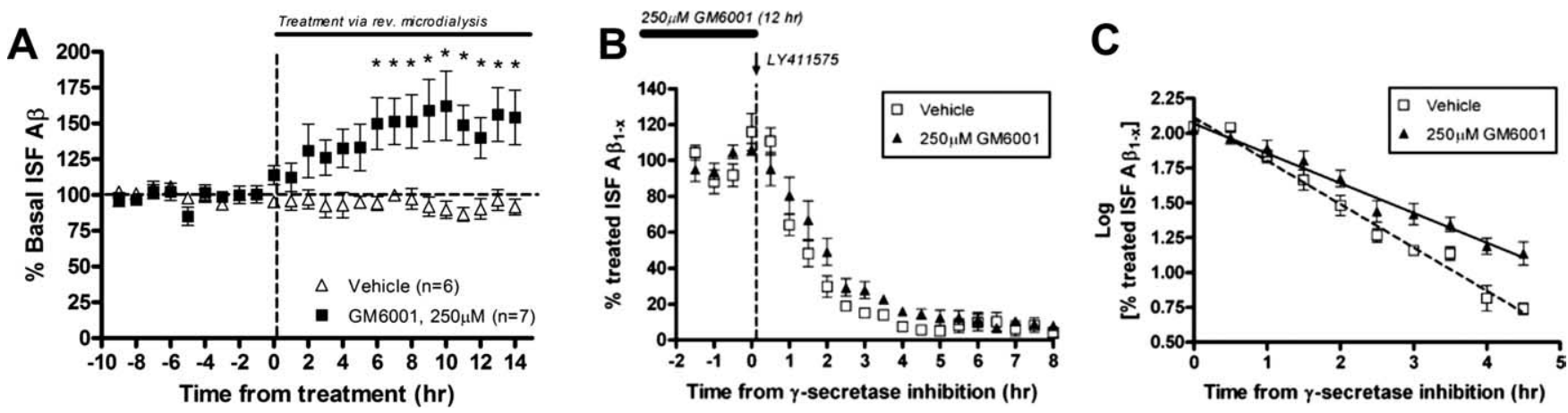

Figure 7. MMP inhibition increases ISF A $\beta$ levels and extends A $\beta$ elimination half-life in young APPsw transgenic mice. $A$, In vivo microdialysis was used to examine ISF $A \beta$ levels within the hippocampus of 3-month-old APPsw mice treated with GM6001. Significant increases in A $\beta$ levels were seen within $6 \mathrm{~h}$ after infusion of GM6001, reaching $\sim 150 \%$ of vehicle-treated mice $\left({ }^{*} p<\right.$ 0.05; repeated-measures ANOVA; $n=6-7$ per group). $B, C$, To measure ISF A $\beta$ elimination half-life in 3-month-old APPsw, mice pretreated with vehicle or $250 \mu \mathrm{m}$ GM6001 (for $12 \mathrm{~h}$ ) were injected with $3 \mathrm{mg} / \mathrm{kg}$ of LY411575, a potent $\gamma$-secretase inhibitor. ISF A $\beta$ levels decreased to $<10 \%$ of basal levels at different rates $(n=5$ per group) (B). The $A \beta$ elimination half-life in ISF was significantly increased by $\sim 50 \%$ in GM6001-treated mice in comparison with vehicle-treated mice ( $p=0.0079 ; n=5$ per group) (C). Error bars indicate SD.

The activation of MMP-2 and -9 requires the presence of other proteases that can cleave and activate the secreted proenzymes. Our detection of both the pro- and active forms of MMP-2 and -9 in ACM and in mouse brain regions suggests the presence of such activating proteases. It is believed that proMMP-2 is activated by membrane-type 1 MMPs (Murphy et al., 1999), which are constitutively expressed in neonatal rat astrocyte cultures (Wells et al., 1996) and are also highly expressed in reactive astrocytes near glioblastomas (Nagashima et al., 2002). Furthermore, pro-MMP-9 can be activated by either MMP-2 or -3 (Yong et al., 1998). Both MMPs are expressed in cultured rat astrocytes, and MMP-3 expression is increased in AD brains and in astrocytes treated with A $\beta$ (Deb and Gottschall, 1996; Yoshiyama et al., 2000). Further investigation is needed to explore the mechanisms of activation of MMP-2 and -9 in astrocytes in the $\mathrm{AD}$ brain.

In summary, we found that MMP-2 and -9 are expressed in activated astrocytes surrounding amyloid plaques in aged APP/ PS1 mice. Furthermore, these proteases appear to play a role in cerebral $\mathrm{A} \beta$ catabolism and clearance in the extracellular compartment both in vitro and in vivo. It is likely that multiple proteases act cooperatively in different cellular compartments to regulate brain $\mathrm{A} \beta$ steady-state levels. Future studies are needed to determine the significance of MMPs in the pathogenesis of $A \beta$ accumulation in APP transgenic mouse models and in AD.

\section{References}

Akiyama H, Barger S, Barnum S, Bradt B, Bauer J, Cole GM, Cooper NR, Eikelenboom P, Emmerling M, Fiebich BL, Finch CE, Frautschy S, Griffin WS, Hampel H, Hull M, Landreth G, Lue L, Mrak R, Mackenzie IR, McGeer PL, et al. (2000) Inflammation and Alzheimer's disease. Neurobiol Aging 21:383-421.

Aoki T, Sumii T, Mori T, Wang X, Lo EH (2002) Blood-brain barrier disruption and matrix metalloproteinase- 9 expression during reperfusion injury: mechanical versus embolic focal ischemia in spontaneously hypertensive rats. Stroke 33:2711-2717.

Backstrom JR, Lim GP, Cullen MJ, Tokes ZA (1996) Matrix metalloproteinase-9 (MMP-9) is synthesized in neurons of the human hippocampus and is capable of degrading the amyloid- $\beta$ peptide (1-40). J Neurosci 16:7910-7919.

Barnes K, Turner AJ, Kenny AJ (1992) Membrane localization of endopeptidase-24.11 and peptidyl dipeptidase A (angiotensin converting enzyme) in the pig brain: a study using subcellular fractionation and electron microscopic immunocytochemistry. J Neurochem 58:2088-2096.

Bennett RG, Duckworth WC, Hamel FG (2000) Degradation of amylin by insulin-degrading enzyme. J Biol Chem 275:36621-36625.

Burbach GJ, Dehn D, Nagel B, Del Turco D, Deller T (2004a) Laser micro- dissection of immunolabeled astrocytes allows quantification of astrocytic gene expression. J Neurosci Methods 138:141-148.

Burbach GJ, Dehn D, Del Turco D, Staufenbiel M, Deller T (2004b) Laser microdissection reveals regional and cellular differences in GFAP mRNA upregulation following brain injury, axonal denervation, and amyloid plaque deposition. Glia 48:76-84.

Burger C, Gorbatyuk OS, Velardo MJ, Peden CS, Williams P, Zolotukhin S, Reier PJ, Mandel RJ, Muzyczka N (2004) Recombinant AAV viral vectors pseudotyped with viral capsids from serotypes 1,2, and 5 display differential efficiency and cell tropism after delivery to different regions of the central nervous system. Mol Ther 10:302-317.

Carson JA, Turner AJ (2002) Beta-amyloid catabolism: roles for neprilysin (NEP) and other metallopeptidases? J Neurochem 81:1-8.

Cirrito JR, May PC, O'Dell MA, Taylor JW, Parsadanian M, Cramer JW, Audia JE, Nissen JS, Bales KR, Paul SM, DeMattos RB, Holtzman DM (2003) In vivo assessment of brain interstitial fluid with microdialysis reveals plaque-associated changes in amyloid- $\beta$ metabolism and half-life. J Neurosci 23:8844-8853.

Cirrito JR, Yamada KA, Finn MB, Sloviter RS, Bales KR, May PC, Schoepp DD, Paul SM, Mennerick S, Holtzman DM (2005) Synaptic activity regulates interstitial fluid amyloid-beta levels in vivo. Neuron 48:913-922.

Deb S, Gottschall PE (1996) Increased production of matrix metalloproteinases in enriched astrocyte and mixed hippocampal cultures treated with beta-amyloid peptides. J Neurochem 66:1641-1647.

Deb S, Wenjun Zhang J, Gottschall PE (2003) Beta-amyloid induces the production of active, matrix-degrading proteases in cultured rat astrocytes. Brain Res 970:205-213.

Duckworth WC, Bennett RG, Hamel FG (1998) Insulin degradation: progress and potential. Endocr Rev 19:608-624.

Eckman EA, Reed DK, Eckman CB (2001) Degradation of the Alzheimer's amyloid beta peptide by endothelin-converting enzyme. J Biol Chem 276:24540-24548.

Eckman EA, Watson M, Marlow L, Sambamurti K, Eckman CB (2003) Alzheimer's disease beta-amyloid peptide is increased in mice deficient in endothelin-converting enzyme. J Biol Chem 278:2081-2084.

Emonard H, Marcq V, Mirand C, Hornebeck W (1999) Inhibition of gelatinase A by oleic acid. Ann NY Acad Sci 878:647-649.

Farris W, Mansourian S, Chang Y, Lindsley L, Eckman EA, Frosch MP, Eckman CB, Tanzi RE, Selkoe DJ, Guenette S (2003) Insulin-degrading enzyme regulates the levels of insulin, amyloid beta-protein, and the betaamyloid precursor protein intracellular domain in vivo. Proc Natl Acad Sci USA 100:4162-4167.

Galardy RE, Cassabonne ME, Giese C, Gilbert JH, Lapierre F, Lopez H, Schaefer ME, Stack R, Sullivan M, Summers B (1994) Low molecular weight inhibitors in corneal ulceration. Ann NY Acad Sci 732:315-323.

Gottschall PE, Yu X, Bing B (1995) Increased production of gelatinase B (matrix metalloproteinase-9) and interleukin- 6 by activated rat microglia in culture. J Neurosci Res 42:335-342.

Herz J (2003) LRP: a bright beacon at the blood-brain barrier. J Clin Invest 112:1483-1485. 
Holcomb L, Gordon MN, McGowan E, Yu X, Benkovic S, Jantzen P, Wright K, Saad I, Mueller R, Morgan D, Sanders S, Zehr C, O’Campo K, Hardy J, Prada CM, Eckman C, Younkin S, Hsiao K, Duff K (1998) Accelerated Alzheimer-type phenotype in transgenic mice carrying both mutant amyloid precursor protein and presenilin 1 transgenes. Nat Med 4:97-100.

Hsiao K, Chapman P, Nilsen S, Eckman C, Harigaya Y, Younkin S, Yang F, Cole G (1996) Correlative memory deficits, Abeta elevation, and amyloid plaques in transgenic mice. Science 274:99-102.

Hu J, Igarashi A, Kamata M, Nakagawa H (2001) Angiotensin-converting enzyme degrades Alzheimer amyloid beta-peptide (A beta); retards A beta aggregation, deposition, fibril formation; and inhibits cytotoxicity. J Biol Chem 276:47863-47868.

Itoh T, Ikeda T, Gomi H, Nakao S, Suzuki T, Itohara S (1997) Unaltered secretion of beta-amyloid precursor protein in gelatinase A (matrix metalloproteinase 2)-deficient mice. J Biol Chem 272:22389-22392.

Iwata N, Tsubuki S, Takaki Y, Shirotani K, Lu B, Gerard NP, Gerard C, Hama E, Lee HJ, Saido TC (2001) Metabolic regulation of brain Abeta by neprilysin. Science 292:1550-1552.

Kawarabayashi T, Younkin LH, Saido TC, Shoji M, Ashe KH, Younkin SG (2001) Age-dependent changes in brain, CSF, and plasma amyloid (beta) protein in the Tg2576 transgenic mouse model of Alzheimer's disease. J Neurosci 21:372-381.

Koistinaho M, Lin S, Wu X, Esterman M, Koger D, Hanson J, Higgs R, Liu F, Malkani S, Bales KR, Paul SM (2004) Apolipoprotein E promotes astrocyte colocalization and degradation of deposited amyloid-beta peptides. Nat Med 10:719-726.

Kurochkin IV (2001) Insulin-degrading enzyme: embarking on amyloid destruction. Trends Biochem Sci 26:421-425.

Lee JM, Yin KJ, Hsin I, Chen S, Fryer JD, Holtzman DM, Hsu CY, Xu J (2003) Matrix metalloproteinase- 9 and spontaneous hemorrhage in an animal model of cerebral amyloid angiopathy. Ann Neurol 54:379-382.

Leissring MA, Farris W, Chang AY, Walsh DM, Wu X, Sun X, Frosch MP, Selkoe DJ (2003) Enhanced proteolysis of beta-amyloid in APP transgenic mice prevents plaque formation, secondary pathology, and premature death. Neuron 40:1087-1093.

Lo EH, Wang X, Cuzner ML (2002) Extracellular proteolysis in brain injury and inflammation: role for plasminogen activators and matrix metalloproteinases. J Neurosci Res 69:1-9.

Marr RA, Rockenstein E, Mukherjee A, Kindy MS, Hersh LB, Gage FH, Verma IM, Masliah E (2003) Neprilysin gene transfer reduces human amyloid pathology in transgenic mice. J Neurosci 23:1992-1996.

Mills JC, Andersson N, Hong CV, Stappenbeck TS, Gordon JI (2002) Molecular characterization of mouse gastric epithelial progenitor cells. Proc Natl Acad Sci USA 99:14819-14824.

Mills JC, Andersson N, Stappenbeck TS, Chen CC, Gordon JI (2003) Molecular characterization of mouse gastric zymogenic cells. J Biol Chem 278:46138-46145.

Muir EM, Adcock KH, Morgenstern DA, Clayton R, von Stillfried N, Rhodes K, Ellis C, Fawcett JW, Rogers JH (2002) Matrix metalloproteases and their inhibitors are produced by overlapping populations of activated astrocytes. Brain Res Mol Brain Res 100:103-117.

Murphy G, Stanton H, Cowell S, Butler G, Knauper V, Atkinson S, Gavrilovic J (1999) Mechanisms for pro matrix metalloproteinase activation. APMIS 107:38-44.

Nagase H, Meng Q, Malinovskii V, Huang W, Chung L, Bode W, Maskos K, Brew K (1999) Engineering of selective TIMPs. Ann NY Acad Sci 878:1-11.

Nagashima G, Suzuki R, Asai J, Fujimoto T (2002) Immunohistochemical analysis of reactive astrocytes around glioblastoma: an immunohistochemical study of postmortem glioblastoma cases. Clin Neurol Neurosurg 104:125-131.

Planas AM, Sole S, Justicia C (2001) Expression and activation of matrix metalloproteinase-2 and -9 in rat brain after transient focal cerebral ischemia. Neurobiol Dis 8:834-846.

Pype S, Moechars D, Dillen L, Mercken M (2003) Characterization of amyloid beta peptides from brain extracts of transgenic mice overexpressing the London mutant of human amyloid precursor protein. J Neurochem 84:602-609.

Qiu WQ, Ye Z, Kholodenko D, Seubert P, Selkoe DJ (1997) Degradation of amyloid beta-protein by a metalloprotease secreted by microglia and other neural and non-neural cells. J Biol Chem 272:6641-6646.

Qiu WQ, Walsh DM, Ye Z, Vekrellis K, Zhang J, Podlisny MB, Rosner MR,
Safavi A, Hersh LB, Selkoe DJ (1998) Insulin-degrading enzyme regulates extracellular levels of amyloid beta-protein by degradation. J Biol Chem 273:32730-32738

Roher AE, Kasunic TC, Woods AS, Cotter RJ, Ball MJ, Fridman R (1994) Proteolysis of A beta peptide from Alzheimer disease brain by gelatinase A. Biochem Biophys Res Commun 205:1755-1761.

Saido TC (1998) Alzheimer's disease as proteolytic disorders: anabolism and catabolism of beta-amyloid. Neurobiol Aging 19:S69-75.

Saito T, Takaki Y, Iwata N, Trojanowski J, Saido TC (2003) Alzheimer's disease, neuropeptides, neuropeptidase, and amyloid-beta peptide metabolism. Sci Aging Knowledge Environ 2003:PE1.

Schwartz JP, Wilson DJ (1992) Preparation and characterization of type 1 astrocytes cultured from adult rat cortex, cerebellum, and striatum. Glia 5:75-80.

Schweizer A, Valdenaire O, Nelbock P, Deuschle U, Dumas Milne Edwards JB, Stumpf JG, Loffler BM (1997) Human endothelin-converting enzyme (ECE-1): three isoforms with distinct subcellular localizations. Biochem J 328:871-877.

Selkoe DJ (1993) Physiological production of the beta-amyloid protein and the mechanism of Alzheimer's disease. Trends Neurosci 16:403-409.

Seta KA, Roth RA (1997) Overexpression of insulin degrading enzyme: cellular localization and effects on insulin signaling. Biochem Biophys Res Commun 231:167-171.

Shibata M, Yamada S, Kumar SR, Calero M, Bading J, Frangione B, Holtzman DM, Miller CA, Strickland DK, Ghiso J, Zlokovic BV (2000) Clearance of Alzheimer's amyloid-ss(1-40) peptide from brain by LDL receptorrelated protein-1 at the blood-brain barrier. J Clin Invest 106:1489-1499.

Silverberg GD, Mayo M, Saul T, Rubenstein E, McGuire D (2003) Alzheimer's disease, normal-pressure hydrocephalus, and senescent changes in CSF circulatory physiology: a hypothesis. Lancet Neurol 2:506-511.

Stine Jr WB, Dahlgren KN, Krafft GA, LaDu MJ (2003) In vitro characterization of conditions for amyloid-beta peptide oligomerization and fibrillogenesis. J Biol Chem 278:11612-11622.

Tamura Y, Watanabe F, Nakatani T, Yasui K, Fuji M, Komurasaki T, Tsuzuki H, Maekawa R, Yoshioka T, Kawada K, Sugita K, Ohtani M (1998) Highly selective and orally active inhibitors of type IV collagenase (MMP-9 and MMP-2): $N$-sulfonylamino acid derivatives. J Med Chem 41:640-649.

Tanzi RE, Kovacs DM, Kim TW, Moir RD, Guenette SY, Wasco W (1996) The gene defects responsible for familial Alzheimer's disease. Neurobiol Dis 3:159-168.

Tucker HM, Kihiko M, Caldwell JN, Wright S, Kawarabayashi T, Price D, Walker D, Scheff S, McGillis JP, Rydel RE, Estus S (2000) The plasmin system is induced by and degrades amyloid- $\beta$ aggregates. J Neurosci 20:3937-3946.

Van den Steen PE, Dubois B, Nelissen I, Rudd PM, Dwek RA, Opdenakker G (2002) Biochemistry and molecular biology of gelatinase B or matrix metalloproteinase-9 (MMP-9). Crit Rev Biochem Mol Biol 37:375-536.

Van Nostrand WE, Porter M (1999) Plasmin cleavage of the amyloid betaprotein: alteration of secondary structure and stimulation of tissue plasminogen activator activity. Biochemistry 38:11570-11576.

Van Uden E, Mallory M, Veinbergs I, Alford M, Rockenstein E, Masliah E (2002) Increased extracellular amyloid deposition and neurodegeneration in human amyloid precursor protein transgenic mice deficient in receptor-associated protein. J Neurosci 22:9298-9304.

Vehmas AK, Kawas CH, Stewart WF, Troncoso JC (2003) Immune reactive cells in senile plaques and cognitive decline in Alzheimer's disease. Neurobiol Aging 24:321-331.

Vekrellis K, Ye Z, Qiu WQ, Walsh D, Hartley D, Chesneau V, Rosner MR, Selkoe DJ (2000) Neurons regulate extracellular levels of amyloid betaprotein via proteolysis by insulin-degrading enzyme. J Neurosci 20:1657-1665.

Vigo-Pelfrey C, Lee D, Keim P, Lieberburg I, Schenk DB (1993) Characterization of beta-amyloid peptide from human cerebrospinal fluid. J Neurochem 61:1965-1968.

Vu TH, Shipley JM, Bergers G, Berger JE, Helms JA, Hanahan D, Shapiro SD, Senior RM, Werb Z (1998) MMP-9/gelatinase B is a key regulator of growth plate angiogenesis and apoptosis of hypertrophic chondrocytes. Cell 93:411-422.

Wang R, Sweeney D, Gandy SE, Sisodia SS (1996) The profile of soluble amyloid beta protein in cultured cell media: detection and quantification 
of amyloid beta protein and variants by immunoprecipitation-mass spectrometry. J Biol Chem 271:31894-31902.

Wegiel J, Wang KC, Tarnawski M, Lach B (2000) Microglia cells are the driving force in fibrillar plaque formation, whereas astrocytes are a leading factor in plague degradation. Acta Neuropathol (Berl) 100:356-364.

Wells GM, Catlin G, Cossins JA, Mangan M, Ward GA, Miller KM, Clements JM (1996) Quantitation of matrix metalloproteinases in cultured rat astrocytes using the polymerase chain reaction with a multi-competitor cDNA standard. Glia 18:332-340.

Woessner Jr JF (1999) Matrix metalloproteinase inhibition. From the Jurassic to the third millennium. Ann NY Acad Sci 878:388-403.

Wyss-Coray T, Mucke L (2002) Inflammation in neurodegenerative disease: a double-edged sword. Neuron 35:419-432.

Wyss-Coray T, Loike JD, Brionne TC, Lu E, Anankov R, Yan F, Silverstein SC, Husemann J (2003) Adult mouse astrocytes degrade amyloid-beta in vitro and in situ. Nat Med 9:453-457.

Yin KJ, Lee JM, Chen SD, Xu J, Hsu CY (2002) Amyloid- $\beta$ induces Smac release via AP-1/Bim activation in cerebral endothelial cells. J Neurosci 22:9764-9770.
Yin KJ, Hsu CY, Hu XY, Chen H, Chen SW, Xu J, Lee JM (2006) Protein phosphatase $2 \mathrm{~A}$ regulates bim expression via the Akt/FKHRL1 signaling pathway in amyloid- $\beta$ peptide-induced cerebrovascular endothelial cell death. J Neurosci 26:2290-2299.

Yong VW, Krekoski CA, Forsyth PA, Bell R, Edwards DR (1998) Matrix metalloproteinases and diseases of the CNS. Trends Neurosci 21:75-80.

Yoshiyama Y, Asahina M, Hattori T (2000) Selective distribution of matrix metalloproteinase-3 (MMP-3) in Alzheimer's disease brain. Acta Neuropathol (Berl) 99:91-95.

Zhang JW, Gottschall PE (1997) Zymographic measurement of gelatinase activity in brain tissue after detergent extraction and affinity-support purification. J Neurosci Methods 76:15-20.

Zlokovic BV (2004) Clearing amyloid through the blood-brain barrier. J Neurochem 89:807-811.

Zolotukhin S, Potter M, Zolotukhin I, Sakai Y, Loiler S, Fraites Jr TJ, Chiodo VA, Phillipsberg T, Muzyczka N, Hauswirth WW, Flotte TR, Byrne BJ, Snyder RO (2002) Production and purification of serotype 1, 2, and 5 recombinant adeno-associated viral vectors. Methods 28:158-167. 